\title{
German Banks as Financial Department Stores
}

\author{
by DIETHER H. HOFFMANN
}

\begin{abstract}
This paper was presented by Dr. Diether H. Hoffmann, Member of the Board of Management of Bank für Gemeinwirtschaft, Frankftrt, at Ohio State University, Columbus, Ohio, on November 30, 1970. He also discussed the paper in the Research Department at the Federal Reserve Bank of St. Louis.
\end{abstract}

\begin{abstract}
$\mathbf{N}$ EN DEVELOPMENTS in the banking industry, greater demands for more adequate services, and the necessity to finance much larger operations have in recent years led many persons in the United States to ask whether the U.S. banking structure is adequate or whether changes should be made. For a discussion of such problems, it is useful to look across borders. Of course, it is impossible to simply copy the system of another country, because both the historical development and the interrelationships with other systems in that country have a bearing on the functioning of a banking system. But a comparison, for example, of the German with the U.S. banking structure at least clarifies alternatives, and even raises certain questions which may not arise if all the elements of a system are taken for granted.
\end{abstract}

I do not think it is appropriate for me to take a position on the current discussions in the United States. This is your discussion, and you as citizens will have to work out the appropriate answers. I shall, therefore, restrict myself to describing how the banking system is organized in Germany. I shall try not to delve too deeply into our history; rather, I shall describe the present situation and some of the discussions prevailing in Germany. ${ }^{1}$

\section{German Financial Institutions}

In the Federal Republic of Germany we have about 8,500 credit institutions: 305 commercial banks; 844

1 All data, uniess otherwise stated, are as of December 31 , 1970 . savings institutions and their central banks; 7,072 cooperative banks and their central institutions; 46 longterm banks; 180 finance companies; and 102 institutions which have special functions discussed later. In addition, we have building societies with total deposits of 40 billion marks (DM) as deposits in the giro system and almost 10 billion $\mathrm{DM}$ as savings deposits. ${ }^{2}$

The credit institutions reporting to our central bank, the Bundesbank, have total deposits from the nonbank public of 447 billion DM. Distribution of these deposits among the credit institutions indicates their relative importance. Commercial banks hold 113 billion DM ( 59 billion DM are held by three banks). Savings institutions and their central banks hold 188 billion DM, of which 126 billion DM are savings deposits. These savings deposits are very steady money which a banker can almost consider as long-term money, even though most of them can be withdrawn on three months' notice. The cooperative banks and their central institutions hold 55.5 billion DM, the largest portion of the remaining 146 billion DM. The credit institutions also have issued bonds amounting to 119 billion DM.

A unique and significant feature of the German banking system is the importance of our savings institutions, most of which are owned by the municipalities. These institutions were established during

2The mark-dollar exchange rate has been about 3.65 . 


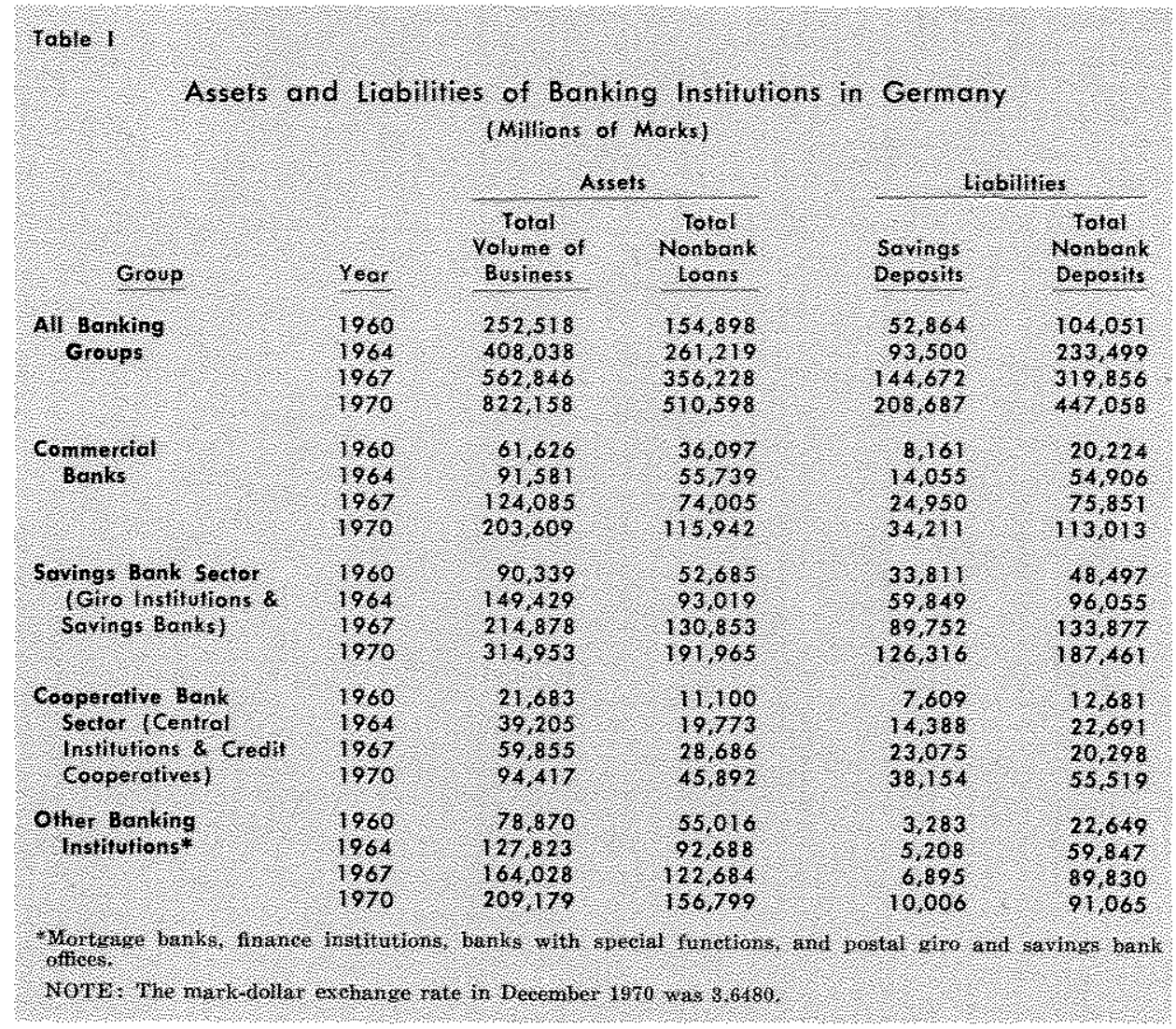

the last century to safeguard the small saver - the laborer, the artisan and the small shopowner - against criminal or immoral practices in general and to encourage the spirit of saving. Considering the size of their deposits, they did very well in fulfilling this task. They also serve their communities by being very active lenders, holding about 23 per cent of all loans extended by credit institutions to the nonbank public. During the last ten years, they have become partners. as well as competitors in almost all the other fields in which commercial banks operate. Their central banks, the Girozentralen, are established in each state and are particularly active in loans to big corporations and in long-term lending. Table I further illustrates the division of business among the various credit institutions.

\section{Competition in the German Banking Industry}

Competition in the German banking industry is very keen. Until a few years ago, however, we had several regulations limiting competition. Government fixed the rates for deposits and loans and even told banks how to advertise and approach their customers. All these limitations were rescinded in 1967. Now the only constraints are those imposed by the market and the cost/eamings structure of each bank, which limit the interest rates paid or demanded. Banks are no longer required to refrain from certain methods of advertising or soliciting new customers, as long as these methods do not violate the national laws on competition, which are stricter than those prevailing in the United States. This new freedom has led to sophisticated promotional incentives for the saver. Debtors are more aware now that interest rates are not dictated by the banks, but can be negotiated.

After four years during which German banks have worked in this more liberal atmosphere, I feel justified in stating that this greater freedom has assisted in enhancing growth in the economy in general, and in particular, has aided the smaller customer. Competition for small deposits and personal loans only became effective after the former limitations were rescinded. Now, banks too have to prove their efficiency to their customers in the free market. In general, they have succeeded in this effort. The fear that increased competition could easily lead to more bankruptcies of smaller banks was unjustified; very few banks have failed during these years.

One of the first promotional incentives was a special savings certificate for the small saver, with interest rates which are not fixed according to the contracted time of deposit, but which rise according to the actual time of deposit. This complements the theory that small deposits have a tendency to stay for a much longer period than agreed upon when the deposit is made. Another incentive was a casualty insurance for the saver. The German insurance authority, however, permitted this practice only under the condition that the saver pay a special premium for the insurance, making such an incentive unattractive as a tool of competition since the premium would have to be deducted openly from the interest rate.

The interest rate for three-month savings deposits, the rate generally considered the guideline for all 
savings and time deposit rates, is currently about 4.5 per cent; for four-year deposits it is up to 7 per cent. Larger sums deposited over the year-end as regular term deposits could earn up to 8.5 per cent. Demand deposits generally bear $1 / 8$ per cent interest. Table II shows the development of the rates for three-month term deposits of sums under one million DM.

The discount rate of the Bundesbank is the guideline for bank loan rates. Short-term business loans are issued at a margin above the discount rate. The prime rate is about 3.5 per cent above the Bundesbank discount rate. Rates for customers which do not get the prime rate are about 1 per cent higher. Who gets prime interest rates generally is decided by the standing of the borrower; other circumstances, such as the amount of business the customer conducts at the bank and his total deposits, are only of secondary importance in this respect. The rates are either flat rates or subject to additional charges, particularly those linked to the turnover on the accounts; the instrument of compensating balances is not in use.

Although there is competition among the banks as far as the margin above the Bundesbank rate is concerned, in general, the Bundesbank's discount rate affects directly the cost of borrowing from a bank. German bankers are discussing the American system of setting the prime rate themselves, which would allow them to consider not only the Bundesbank rate, but also other factors influencing the cost of money, including the domestic money market. We have made slight changes in this direction during the last two years, but it is too early to forecast our further course in rate policy.

The picture of our short-term lending activities would not be complete unless I describe a special type of short-term financing practiced by German banks. We discount bills from our customers. These bills must be due within three months, bear two "good" signatures, and must be drawn in connection with a sale of goods. Then, they are rediscounted by the Bundesbank. We add a small margin above the Bundesbank rate. This margin is lower than for loans for which this special method of refinancing is not provided. For many years it was .5 to 1 per cent; with recent increases in the cost of money, it has risen to 2 per cent. This method reduces considerably the average cost of short-term financing for clients who can use this kind of credit. Other methods of financing have only minor importance in the short-term market. The U.S. system-especially with its commercial paper market - seems to be far more sophisticated.

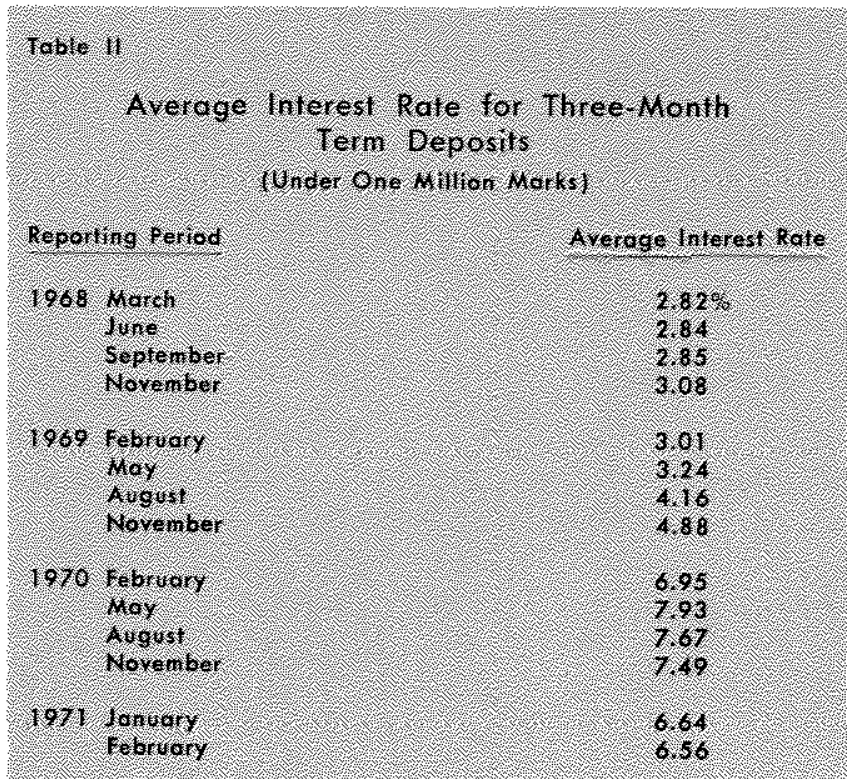

While the rates for short-term loans are flexible, long-term rates and consumer credit rates are fixed. This applies to long-term loans when issued by mortgage banks and paid out of the proceeds of mortgagesecured bonds, which only these special banks can sell. These rates recently have been above 9 per cent. They cannot be changed by the bank or the customer during the time of the loan, which may be up to 33 years. Long-term loans not given by these special banks, but by commercial banks or savings institutions are, of course, linked either to the Bundesbank rate or to the cost of money. For consumer loans the rates are fixed at the time they are made, thus allowing the banks to quote a fixed amount for both amortization and interest which the client has to pay each month.

\section{Loan Actwicy Abroad}

With the Deutsche Mark freely convertible, and since for a long time we have had little exchange control, German bankers are allowed to make loans to any foreign company anywhere in the industrialized world as well as in developing countries. In 1969 especially, German banks were large exporters of capital. They made loans of almost 25 billion DM, a large portion of which was long-term money. This capital export continued through April of 1970 with an increase of 2.5 billion DM. But then it stopped, and there was a light counterflow, since the burden had been too heavy for the German banking system as a whole. Most of these loans have been portfolio investments rather than regular export financing. For export financing, our banks, not the government, set 
up a special institution to make loans at comparatively low rates.

\section{Scope of Business}

Most of the functions mentioned so far can be performed by both the commercial banks and the savings institutions. They all are allowed to make short-term commercial, long-term, and consumer loans, and to accept demand, time and savings deposits. They participate in the clearing system for money transfers established by the Bundesbank, and their customers can use their services by drawing checks or signing transfer orders, which is the more common method of paying a bill in Germany. Only mortgage banks and the Girozentralen, the central banks of the savings institutions, can issue and sell mortgage-secured bonds. The Girozentralen have the largest range of activities; they are permitted to do all things savings institutions and commercial banks can do, in addition to selling mortgage-secured bonds. It is therefore no wonder that the largest bank in the Federal Republic is the Westdeutsche Landesbank, the Girozentrale serving the heavy industrial Ruhr area.

Regular mortgage banks, in extending long-term loans against first mortgages on buildings or to public authorities, are limited to the use of funds received from the sale of their bonds. They may not accept regular deposits, which prevents them from extending short-term loans. This rule has two important exceptions: because their charter was issued in the middle of the last century, two Bavarian banks have the same right as the Girozentralen; that is, they can perform all the activities in short- and in long-term business.

Further limitations apply to special institutions; finance companies may extend only installment loans, both as consumer credit and as loans financing the sale of machinery to smaller companies. Other credit institutions are factoring and leasing companies. The latter have only recently been established and have not been too active - partly because tax problems remain to be solved.

\section{Rank Suluchute}

Our banking laws thus are very liberal. There are two major prerequisites for opening a bank in Germany: sufficient capital of 5 million DM (although several smaller banks established earlier only have 1 or 2 million DM as capital plus reserves) and competent management. Until 1962 the banking authority had the right to decide whether there was an eco- nomic need for the establishment of a new bank; however, this provision was found unconstitutional by our Supreme Administrative Court and was rescinded.

Once a bank is established, the number of branches it wishes to operate is unlimited. There is little or no restriction as to the area where these branches may be opened. Legally, all banks could have branches all over the country. Only the savings institutions are restricted; their charters limit them to the municipality to which they belong. Similar restrictions limit the Girozentralen to the states of the savings institutions they represent. Nevertheless, we only have four banks which have nationwide branches - Deutsche Bank, Dresdner Bank, Commerzbank and Bank für Gemeinwirtschaft. To give you a picture of their size, Deutsche Bank has total assets of 31 billion DM, and Bank für Gemeinwirtschaft has 12 billion DM. The four banks together attracted about 12 per cent of the total deposits held by German credit institutions.

There are more than 32,000 branches of credit institutions in Germany. This, added to the 8,500 established head offices, means that altogether there are over 40,000 locations in which the services of a bank or some other financial institution are offered. Compared with a population of over 60 million, there is one bank location per 1,500 inhabitants. 1 understand that in the United States, one bank or savings bank serves an average of 5,700 inhabitants.

The picture becomes clearer when one breaks down these figures by groups of credit institutions; of those 40,000 offices, over 16,000 belong to the savings institutions and their central banks, more than 18,000 to the cooperative banks, and 5,300 to the commercial banks, of which the four banks operating on a nationwide basis have almost 3,000 . If you think of the amount of savings deposits drawn in by German savings institutions and their network of branches, it is understandable why even the smallest child thinks first of the Sparkasse (the savings institution) when he is asked to put some money aside.

Of the 40,000 offices mentioned, 47 are operated by 24 foreign banks, mostly U.S. banks. Although the banking authority could refuse a concession to them on the grounds that the German constitution guarantees the freedom to do business only to indigenous corporations, it has been very liberal and granted the concession if the applying bank was of good standing and provided qualified management for the branch. Difficulties arose in only one case - the Intra Bank of Beirut which discontinued operations - but no credi- 
tor in Germany was hurt since the branch had enough capital at its disposal, and business inside Germany had not contributed to the failure of this bank.

German laws, on the other hand, do not impose any limitation on German banks if they want to go abroad. However, operations within our economy have, so far, proven to be more appealing than foreign opportunities. Thus, you find only a few branches or subsidiaries of German banks in other countries. New forms of intemational cooperation with German banks as partners have been developed only recently.

\section{Regulations and Limitations on Ceman Banks}

So far you have heard only of very liberal provisions of the law and a very liberal attitude of the banking authority in Germany. You might, therefore, wonder if the banks in our country are free from controls. The answer to this question is clearly no. Rather strict regulations limit the activities of a bank in its lending by stipulating that the total amount of its loans must be in certain proportions to its capital plus reserves, to its long-term and savings deposits, and to its total liabilities. This is a rather complicated, but very effective, regulation. So far it has prevented serious cases of bankruptcies of German banks. In the few cases where bankruptcy has occurred, other banks have provided the money necessary to insure the smaller savers against loss.

There is no state insurance for depositors as in the United States. However, in 1969, the banking community established several funds which would pay up to $10,000 \mathrm{DM}$ to each depositor in case of a bankruptcy. Further limitations include minimum reserve requirements, which were particularly effective during recent months when the Bundesbank tried to restrict the inflow of money from abroad.

\section{Oher Actuthes of Geman Banks}

This may all sound familiar to the American banker so far. There are, however, two other specific functions of German banks. They can own stock in other companies - banks or nonbanks - and they can operate as stock brokers.

The banking crisis which occurred in our country in 1931 was due mainly to bad management in loan operations. If the government had not intervened, heavy losses on loans would have led to the bankruptcy of several leading banks. It was the loan and not the stock market business which was at the root of the difficulties. Therefore, the question which was discussed at great length in your country after 1929
- whether banks should continue to do business on the stock exchange - was not considered very important in Germany. Banks continued to be the only agents of the stock exchange - both for their customers and their own portfolios. This means that in practice almost all transactions in shares are done through the banks, and the orders must be executed at the stock exchange, although there is no legal provision to this effect.

Again and again the question arises as to whether the example of the United States, in which broker and bank business is separated, should be followed. Only serious examples of mismanagement, however, could lead German legislators to change a structure which so far seems to have worked rather satisfactorily. Two arguments are raised whenever this question is discussed. First of all, it is said that banks are interested in making loans; therefore, they may use their influence to keep corporations from attracting funds in the stock market. However, this argument neglects the main obstacle against the issue of new shares: corporations prefer to pay interest on a loan rather than leaving half of their earnings to the tax authorities. As long as there is this differential tax treatment of interest and dividends, corporations will prefer to borrow from banks to acquire funds.

Compared with the United States, we have an underdeveloped stock market. Geman savers invest in a more speculative manner, such as buying stock, only after having put a certain amount of money into a savings deposit. To be objective, one must admit that until recently German banks were not very eager to sell stocks or mutual funds. Although some of these funds were already established in the 1950's, it was the promotional activity and success of Investors Overseas Services Ltd. (IOS) and other American organizations that caused bankers to realize that their customers were interested in this service also. Now, German commercial banks are trying to innovate in this field. Mutual fund sales totaled $390 \mathrm{mil}-$ lion DM in 1960; in 1969 the German public purchased 5.5 bilion DM of mutual funds, while foreign mutual funds sold 2.1. billion DM.

The Investors Overseas Services Ltd. crisis brought a sharp reduction in total mutual fund sales during 1970; all funds sold totaled only 1.5 billion DM. New changes may result from the discussion of whether savings institutions should form holding companies and sell shares of these companies to their clients, especiatly to the small savers.

The second argument brought forth against the banks in their capacity as brokers is that they exercise 
an enormous influence on the German economy by means of directorships in most of the important German companies. Bear in mind that the German stockholder generally leaves his shares with his bank and gives the bank power-of-attorney to represent him at shareholders' meetings, exercising all his rights for him including his voice. This, of course, makes it easy for the banks to have their officers elected as directors of the companies. Until a new law in 1966 limited to ten the number of directorships one person could hold, one banker was a director of more than 30 companies. Now, of course, he and his colleagues in the banking community are limited by law, but it cannot be denied that their influence through directorships is rather strong.

The only question $\mathrm{I}$ am asking in this connection is whether there really is a better method of safeguarding the interests of the small shareholder. I personally am not sure that the method prevailing in your country, which in general results in management electing the directors of a company, really provides a better system of control than ours.

Of course, this influence of banks on the economy becomes even stronger when backed by an important participation by the bank itself. This leads us to the other feature which I mentioned before. German banks are only limited in one way as far as participations are concemed. Their investments in participations and real estate must not be higher than their capital plus reserves.

This legal situation has enabled German banks to be promoters of new companies, to buy shares from a major shareholder who wanted to dispose of his hold. ing, or to take over a company which ran into diffi. culties. Transactions of this kind have attracted the attention of the public again and again, not only at the beginning of the era of industrialization, but also recently.

It is the philosophy of my bank that permanent participations should be made only if they are connected either with the services usually rendered by banks or with the activities of our shareholders, which are trade unions and consumer cooperatives. Follow- ing this guideline, we have participations in our own banks and finance companies in Switzerland, Israel, Luxemburg, and the Netherlands, a merchant bank, two finance companies, two mortgage banks in Germany, three insurance companies, and a travel agency. In addition, we own one-third of the stock of the wholesale company of the German consumers' cooperatives.

Other banks do not follow similar guidelines restricting their policy for participations. They are also important shareholders in large industrial corpora tions. Deutsche Bank alone owns more than 25 per cent of the following large corporations: Germany's biggest shipping company, Hapag Loyd; the large sugar company, Suiddeutsche Zucker; and one of the two largest department store chains, Karstadt. Another 25 per cent of the latter is held by Commerzbank, which at the same time is a major stockholder in the other big department store chain, Kaufhof. Furthermore, Commerzbank is involved as shareholder in breweries, another construction firm, and a hotel chain.

I would like to mention briefly the role of service organizations. Consultant firms for legal and tax matters are permitted only under private partnerships. However, banks may enter into the fields of auditing, accounting, management consulting, and particularly, computer services. These may be the fields of the future. So far, banks have not really discovered them.

\section{Conclusions}

All this may have given you the impression that German banks are acting more as conglomerates than as finance institutions. However, you may be assured that they have played an important role in attracting and lending the money necessary for our reconstruction and growth, and Germany has thus fared very well. We do not close our eyes against the dangers of such a very liberal structure, and international comparison is of great importance in this respect. There is hesitancy, however, to forcefully impose changes on a system that has a long tradition and so far has proven its efficiency. 